\title{
KEMAMPUAN RETENSI AIR DAN KETAHANAN PENETRASI TANAH PADA SISTEM OLAH TANAH INTENSIF DAN OLAH TANAH KONSERVASI
}

\section{Water Retention Capacity and Resistence of Soil Penetration in Intensive Tillage System and Conservation Soil Tillage}

\author{
Enny Dwi Wahyunie1)*, Dwi Putro Tejo Baskoro1), dan Mohammad Sofyan²) \\ 1) Departemen Ilmu Tanah dan Sumberdaya Lahan, Fakultas Pertanian IPB, J1. Meranti Kampus IPB Darmaga \\ Bogor 16680 \\ 2) Alumni Departemen Ilmu Tanah dan Sumberdaya Lahan Fakultas Pertanian, Institut Pertanian Bogor, \\ Jl. Meranti, Kampus IPB Darmaga, Bogor 16680
}

\begin{abstract}
A research to study a long term influence of soil management systems on water availability-related soil properties has been carried out in Darmaga Bogor. The experiment was conducted in area with conventional intensive tillage system (OTI) and conservation tillage systems (OTK) in dry-farming agriculture in the clay soils (Oxic Dystrudepts) with seasonal crops rotation. The two tillage systems have been practice in the area for more than 12 years. Water retention characteristics and penetrability of soil from the two tillage system were compared. Conventional intensive tillage system appreciably reduced soil organic matter content as compared to conservation tillage. Similar tendency is also found for water retention characteristics. Field capacity, available water capacity, and field water contents are lower in OTI than in OTK, whereas soil penetrability is higher in OTI than that in OTK. A relatively high differences of soil penetrability in the soil profile under intensive tillage system has been observed, possibly due to the compaction of the sub soil.
\end{abstract}

Keywords: Penetrability, tillage, water retention

\section{ABSTRAK}

Sebuah penelitian untuk mempelajari pengaruh jangka panjang sistem pengelolaan tanah terhadap ketersediaan air terkait dengan sifat-sifat tanah yang dilakukan di Darmaga Bogor. Penelitian ini dilakukan di daerah dengan sistem konvensional olah tanah intensif (OTI) dan sistem olah tanah konservasi (OTK) di lahan pertanian kering pada tanah liat (Oxic Dystrudepts) dengan rotasi tanaman semusim. Kedua sistem pengolahan tersebut telah diterapkan di daerah tersebut selama lebih dari 12 tahun. Karakteristik retensi air dan penetrasi tanah dari kedua sistem pengolahan dibandingkan. Sistem konvensional olah tanah intensif dapat mengurangi kandungan bahan organik tanah jika dibandingkan dengan pengolahan tanah konservasi. Kecenderungan serupa juga ditemukan untuk karakteristik retensi air. Kapasitas lapang, kapasitas air tersedia, dan kadar air tanah lebih rendah di OTI daripada di OTK, sedangkan penetrasi tanah lebih tinggi pada OTI dibanding OTK. Hasil pengamatan menyatakan bahwa secara relatif tingginya penetrasi tanah dalam profil tanah di bawah sistem olah tanah intensif karena adanya pemadatan sub soil.

Kata kunci: Penetrasi, pengolahan, retensi air

\section{PENDAHULUAN}

Usaha pengembangan pertanian pada saat ini umumnya dilakukan pada lahan kering. Kenyataan ini tidak bisa dipungkiri mengingat bahwa lahan kering merupakan sumberdaya pertanian terbesar di Indonesia (Sudharto et al., 1995 dalam Syam et al., 1996). Meskipun demikian usahatani pada agroekosistem ini umumnya masih diwarnai oleh rendahnya produksi yang berkaitan erat dengan rendahnya produktivitas lahan.

Salah satu usaha yang sering dilakukan untuk meningkatkan produktivitas lahan kering adalah dengan menerapkan pengolahan tanah secara intensif. Pengolahan tanah intensif ditujukan untuk memperbaiki "soil tilth" sehingga pertumbuhan akar menjadi lebih baik. Namun, pengelolaan lahan yang intensif serta budidaya monokultur tanpa rotasi dan pendaur - ulangan bahan organik telah terbukti mengakibatkan kelesuan lahan, hilangnya bahan organik tanah, degradasi tanah, dan penurunan produktivitas lahan (Bergeret, 1977). Gliessmann (2007) juga menyatakan bahwa teknologi pertanian yang bertumpu pada pengolahan tanah intensif dan budidaya monokultur dapat menyebabkan degradasi dan penurunan kesuburan tanah. Oleh karena itu praktek pertanian konvensional yang mengandalkan pengolahan tanah intensif harus diubah dan dikonversikan menjadi sistem pertanian yang dapat menjaga kualitas tanah secara berkelanjutan.

Sistem pengolahan tanah yang dapat diterapkan agar kualitas tanah dapat terjaga adalah sistem olah tanah 
konservasi (Sinukaban, 1990). Olah tanah konservasi dapat mempertahankan produktivitas tanah tetap tinggi (Brown et al., 1991). Namun demikian kelebihan yang dihasilkan oleh sistem pengolahan tanah konservasi seperti menghemat tenaga dan waktu, meningkatkan kandungan bahan organik, meningkatkan ketersediaan air dalam tanah, memperbaiki kegemburan dan porositas tanah masih seringkali diperdebatkan. Beberapa hasil penelitian melaporkan bahwa sistem olah tanah konservasi tidak mempengaruhi hasil tanaman (Rao and Dao, 1991) bahkan dapat menyebabkan terjadinya penurunan hasil tanaman (Swan et al., 1991; Ketcheson, 1980).

Salah satu faktor yang menentukan produktivitas lahan kering adalah kondisi kadar air tanah yang sangat tergantung pada curah hujan sebagai sumber air utama. Sebagian besar kebutuhan air tanaman di ambil dari dalam tanah. Air yang diserap tanaman adalah air yang berada dalam pori-pori tanah di lapisan perakaran. Oleh karena itu kemampuan tanah dalam memegang air merupakan faktor utama yang menentukan pertumbuhan dan produksi tanaman. Lebih jauh, rendahnya kemampuan tanah memegang air akan menyebabkan kadar air tanah cepat menurun. Penurunan kadar air tanah biasanya akan diikuti oleh meningkatnya ketahanan penetrasi tanah sehingga secara fisik akan menghambat pertumbuhan akar.

Dengan latar belakang seperti diuraikan diatas, maka dilakukan penelitiaan yang bertujuan untuk mengetahui dan membandingkan sifat retensi air dan ketahanan penetrasi tanah pada sistem olah tanah intensif dan sistem olah tanah konservasi.

\section{BAHAN DAN METODE}

\section{Tempat Penelitian}

Penelitian dilakukan di Kebun Percobaan Cikabayan, Fakultas Pertanian, Institut Pertanian Bogor, Desa Babakan, Kecamatan Dramaga, Kabupaten Bogor, Jawa Barat.

\section{Pelaksanaan Penelitian}

Penelitian ini dilakukan di lapang dan laboratorium dengan sifat fisik tanah yang diamati meliputi kurva pF, kadar air lapang, dan ketahanan penetrasi tanah. Sebagai data pendukung ditetapkan juga tekstur dan kandungan bahan organik tanah. Kadar air lapang, kurva PF, tekstur, dan kandungan bahan organik ditetapkan dilaboratorium, sedangkan ketahanan penetrasi tanah diukur langsung di lapang.

Pengukuran ketahanan penetrasi tanah dan pengambilan contoh tanah untuk kadar air lapang dan kurva $\mathrm{pF}$ di lakukan di lahan yang mengalami pengolahan secara intensif (OTI), dengan membatasi 3 petakan (sebagai ulangan) yang masing-masing luasnya $5 \mathrm{~m}$ x $5 \mathrm{~m}$. Pengukuran ketahanan penetrasi tanah dan kadar air lapang untuk satu ulangan dilakukan sebanyak 10 kali.

Sebagai pembanding, pengukuran ketahanan penetrasi dan pengambilan contoh tanah juga dilakukan pada lahan yang diolah dengan sistem olah tanah konservasi (OTK) yang berjarak sekitar $30 \mathrm{~m}$ dengan kondisi topografi yang relative sama.

\section{Analisis Data}

Data yang diperoleh dianalisis secara statistik menggunakan Analisis of Varian (Anova) untuk melihat faktor yang mempengaruhi respon (parameter) dan uji lanjut Duncan untuk melihat nilai respon (parameter) yang memiliki perbedaan nyata pada taraf $5 \%(\alpha=0.05)$.

\section{HASIL DAN PEMBAHASAN}

\section{Kondisi Umum Lokasi Penelitian}

Pengolahan tanah intensif pada penelitian ini telah diterapkan selama 15 tahun sejak tahun 1996. Pada sistem ini pengolahan tanah dilakukan secara maksimal dengan membalik-balikan/membongkar tanah hingga kedalaman $\pm 20 \mathrm{~cm}$, dilakukan berulang-ulang setiap sebelum penanaman dan tanpa pemanfaatan sisa-sisa tanaman dan gulma sebagai mulsa dan sumber bahan organik.

Pengolahan tanah konservasi telah diterapkan selama 11 tahun sejak tahun 2000. Teknik pengolahan tanah konservasi yang diterapkan adalah pengolahan tanah strip yang dipadukan dengan pengolahan tanah minimum. Pada sistem olah tanah ini, pengolahan tanah dilakukan seperlunya yaitu hanya pada strip-strip atau alur-alur yang akan ditanami yang dibuat mengikuti kontur. Bagian lahan di antara dua strip dibiarkan tidak diolah/terganggu dan sisa-sisa tanaman serta gulma disebar atau diletakan di antara dua strip sebagai mulsa dan menyisakan zona sekitar strip tanpa adanya mulsa.

Karakteristik umum tanah (tekstur dan bahan organik) pada lahan pengolahan tanah konservasi dan lahan pengolahan tanah intensif disajikan pada Tabel 1.

Tabel 1. Tekstur dan kandungan bahan organik di lokasi penelitian.

\begin{tabular}{|c|c|c|c|c|}
\hline \multirow{2}{*}{ Sifat tanah } & \multicolumn{2}{|c|}{$\begin{array}{l}\text { Lahan olah tanah } \\
\text { intensif (OTI) }\end{array}$} & \multicolumn{2}{|c|}{$\begin{array}{l}\text { Lahan olah tanah } \\
\text { konservasi (OTK) }\end{array}$} \\
\hline & $0-20 \mathrm{~cm}$ & $20-40 \mathrm{~cm}$ & $0-20 \mathrm{~cm}$ & $20-40 \mathrm{~cm}$ \\
\hline \multicolumn{5}{|l|}{ Tekstur } \\
\hline Pasir (\%) & 4.6 & 5.05 & 6.98 & 6.48 \\
\hline Debu $(\%)$ & 13.3 & 12.8 & 16.9 & 12.4 \\
\hline Liat $(\%)$ & 82.1 & 82.2 & 76.2 & 81.2 \\
\hline Kelas & Liat & Liat & Liat & Liat \\
\hline $\begin{array}{l}\text { Bahan Organik } \\
(\%)\end{array}$ & 2.3 & 1.5 & 3 & 1.9 \\
\hline C-Organik (\%) & 1.33 & 0.87 & 1.74 & 1.1 \\
\hline
\end{tabular}

Tabel 1 menunjukan bahwa lahan pengolahan tanah konservasi dan lahan pengolahan tanah intensif sama-sama memiliki tekstur liat pada kedalaman $0-30 \mathrm{~cm}$ dan $30-60 \mathrm{~cm}$. Kandungan bahan organik pada lahan pengolahan tanah konservasi lebih tinggi dibandingkan dengan lahan pengolahan tanah intensif. Hal ini karena adanya pemanfaatan sisa-sisa tanaman dan gulma sebagai penutup tanah dan sumber bahan organik. Pemberian sisa tanaman sebagai mulsa nyata meningkatkan bahan organik tanah (Tryono, 2007). 


\section{Sifat Retensi Air Tanah}

Sifat retensi air tanah yang mencerminkan kemampuan tanah memegang air dapat dilihat dari kurva kharakteristik air tanah dan kadar air lapang. Kurva kharakteristik air tanah menunjukkan jumlah air yang masih dapat ditahan oleh tanah setelah diberi tekanan tertentu ( $\mathrm{pF}$ tertentu). Jumlah air maksimum yang dapat ditahan oleh dianggap setara dengan kadar air kapasitas lapang yang didefinisikan sebagai "kadar air tanah di lapang pada saat air drainase karena gravitasi sudah berhenti atau hampir berhenti mengalir setelah sebelumnya tanah tersebut mengalami jenuh sempurna" (Dani dan Wrath, 2000). Secara praktis, kadar air kapasitas lapang diukur di laboratorium dengan mengukur kadar air pada hisapan matrik pF 2.54. Kadar air lapang menggambarkan jumlah air yang masih berada dalam tanah dilapang.

\section{Karakteristik Kelembaban Tanah}

Karakteristik kelembaban tanah yang diekspresikan dalam bentuk kurva hubungan antara kadar air tanah dengan hisapan matriks $(\mathrm{pF})$ pada lahan dengan olah tanah intensif dan konservasi disajikan pada Gambar 1 .

Gambar 1 menunjukkan bahwa pada nilai $\mathrm{pF}$ yang sama, lahan olah tanah intensif selalu memiliki kadar air yang lebih rendah dibandingkan dengan lahan olah tanah konservasi. Pada $\mathrm{pF}$ 2.54, kadar air tanah dengan sistem olah tanah intensif adalah $42.5 \%$ untuk lapisan atas dan $42.5 \%$ untuk lapisan bawah, sedangkan untuk tanah dengan sistem olah tanah konservasi adalah $46.6 \%$ dan $45.5 \%$. Pada $\mathrm{pF} 4.2$, kadar air tanah dengan sistem olah tanah intensif adalah $35.1 \%$ untuk lapisan atas dan 35.04 $\%$ untuk lapisan bawah, sedangkan untuk tanah dengan sistem olah tanah konservasi adalah $36.7 \%$ dan $36.8 \%$.

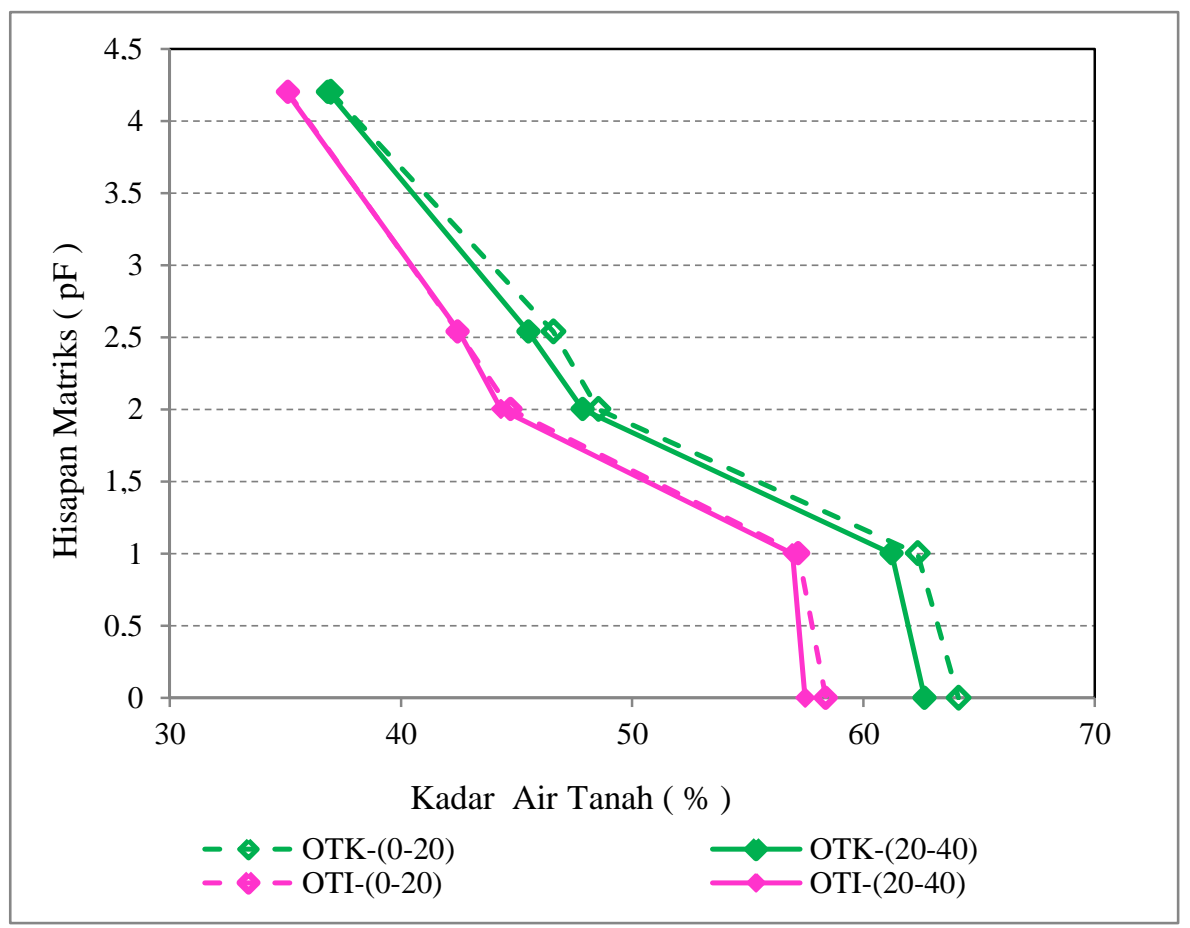

Gambar 1. Kurva pF berdasarkan jenis pengolahan dan kedalaman tanah.

Hasil penelitian juga menunjukkan bahwa kapasitas air tersedia (KA pF $2.54-\mathrm{KA} \mathrm{pF}$ 4.2) tanah pada sistem olah tanah intensif lebih rendah dari pada sistem olah tanah konservasi. Keadaan ini menunjukkan bahwa tanah dengan sistem olah intesif mempunyai distribusi ukuran pori yang lebih buruk dibandingkan tanah dengan sistem olah konservasi. Kandungan bahan organik pada lahan pengolahan tanah konservasi yang lebih tinggi dibandingkan dengan lahan pengolahan tanah intensif akibat adanya pemanfaatan sisa-sisa tanaman dan gulma sebagai penutup tanah dan sumber bahan organik merupakan penyebab terjadinya kondisi seperti tersebut di atas. Di samping itu penerapan sistem olah tanah intensif dengan membalik-balikan/membongkar tanah secara maksimal menyebabkan terjadinya dispersi agregat serta penyumbatan pori yang dapat mengakibatkan menurunnya pori makro dan meningkatnya pori mikro.

\section{Kadar Air lapang}

Hasil pengukuran kadar air lapang selama 5 hari berturut-turut tanpa ada hujan menunjukkan bahwa kadar air tanah menurun dengan waktu. Pada awalnya penurunan kadar air tanah terjadi dengan cepat dan kemudian melambat seperti ditunjukkan pada Gambar 2. Namun demikian tampak bahwa penurunan kadar air tanah tidak pernah berhenti sempurna seperti ditunjukkan oleh kurva yang tidak menjadi datar. Hal ini sejalan dengan pendapat Dani dan Wrath (2000) serta Baskoro dan Tarigan (2007) yang mengemukakan bahwa kadar air tanah yang konstan tidak pernah terjadi. 


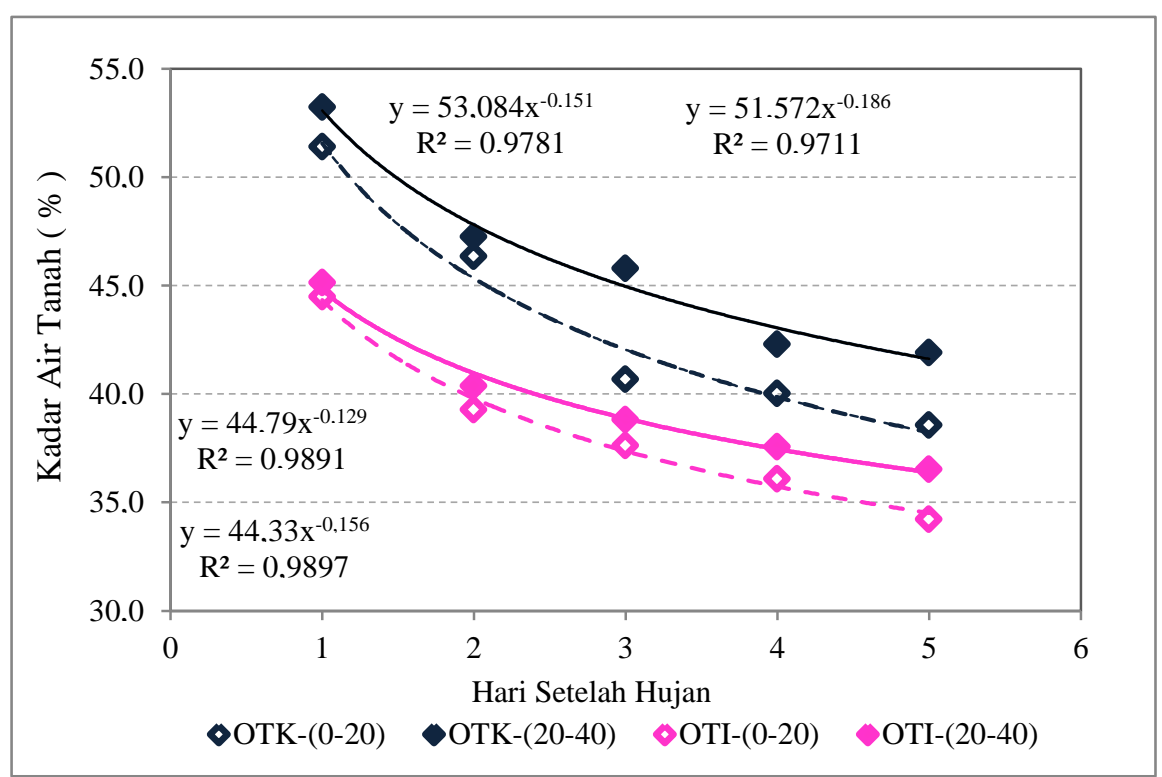

Gambar 2. Kadar air lapang pada berbagai jenis pengolahan tanah, kedalaman tanah dan beberapa hari setelah hujan.

Gambar 2 juga menunjukan bahwa dari hari ke hari setelah hujan kadar air tanah di lapang pada tanah dengan sistem olah intensif selalu lebih rendah dari tanah dengan sistem olah konservasi, baik di lapisan atas maupun lapisan bawah. Hal ini mendukung data hasil pengukuran sifat retensi air tanah (kurva pF) yang menunjukkan bahwa kemampuan tanah menahan air pada sistem olah tanah intensif lebih buruk dari pengolahan tanah konservasi lebih baik dari sistem olah konservasi.

Tabel 2. Persamaan regresi dan koefisien determinasi sertaTLP dan lama hari untuk mencapai TLP pada sistem olah tanah intensif dan sistem olah konservasi

\begin{tabular}{lcccc}
\hline $\begin{array}{c}\text { Kondisi } \\
\text { Lahan }\end{array}$ & Persamaan regresi $^{1)}$ & $\mathrm{R}^{2}$ & TLP & $\begin{array}{c}\text { Hari TLP } \\
\text { tercapai }\end{array}$ \\
\hline LOTI -1 & $\mathrm{Y}=44.33 \mathrm{X}^{-0.15}$ & 0.989 & 35.1 & 5 \\
LOTI -2 & $\mathrm{Y}=44.79 \mathrm{X}^{-0.12}$ & 0.989 & 35.0 & 8 \\
LOTK- 1 & $\mathrm{Y}=51.57 \mathrm{X}^{-0.18}$ & 0.971 & 37.0 & 7 \\
LOTK -2 & $\mathrm{Y}=53.08 \mathrm{X}^{-0.15}$ & 0.978 & 36.9 & 12 \\
\hline
\end{tabular}

Catatan : ${ }^{1)}$ Persamaan regresi menggambarkan hubungan antara kadar air tanah (Y) dengan hari setelah hujan (X), yang digunakan untuk menduga hari tercapainya kadar air titik layu permanen (TLP)

Jika dikaitkan dengan kadar air titik layu permanen $(35.1 \%$ pada lahan olah tanah intensif dan $36.9 \%$ pada lahan olah tanah konservasi), lahan dengan sistem olah tanah intensif pada hari ke-5 sudah mempunyai kadar air yang lebih rendah dari kadar air titik layu permanen (TLP). Artinya, pada sistem olah tanah intensif akar tanaman tidak akan dapat lagi mengambil air dari tanah di kedalaman $0-10 \mathrm{~cm}$ jika tidak ada hujan selama 5 hari berturut-turut. Sementara pada sistem olah tanah konservasi, pada hari ke- 5 kadar air lapang masih lebih tinggi dari kadar air TLP.

Berdasarkan pendugaan yang dilakukan dengan menggunakan persamaan regresi kadar air lapang dan waktu (hari), nilai TLP pada sistem olah tanah konservasi baru akan terlampaui pada hari ke 7 untuk tanah lapisan atas dan hari ke 12 untuk tanah lapisan bawah (Tabel 2).

\section{Ketahanan Penetrasi Tanah}

Nilai ketahanan penetrasi pengolahan tanah konservasi dan pengolahan tanah intensif disajikan pada Gambar 3. Pada Gambar 3 terlihat bahwa nilai ketahanan penetrasi tanah pada lahan dengan sistem olah tanah intensif jauh lebih tinggi dibandingkan lahan pengolahan tanah konservasi, baik di kedalaman 0-10 cm maupun 10$20 \mathrm{~cm}$. Hal ini menunjukan bahwa tanah dengan sistem olah intensif lebih keras dibandingkan dengan tanah dengan sistem olah konservasi, sehingga akar tanaman lebih sulit menembus tanah untuk mengambil air dan hara. Seperti yang dikemukakan dalam Brady and Weil (2002), bahwa cara pengolahan tanah sangat mempengaruhi hasil pengolahan tanah, struktur, bobot isi, dan ruang pori tanah yang pada gilirannya akan mempengaruhi tingkat kepadatan suatu tanah. 


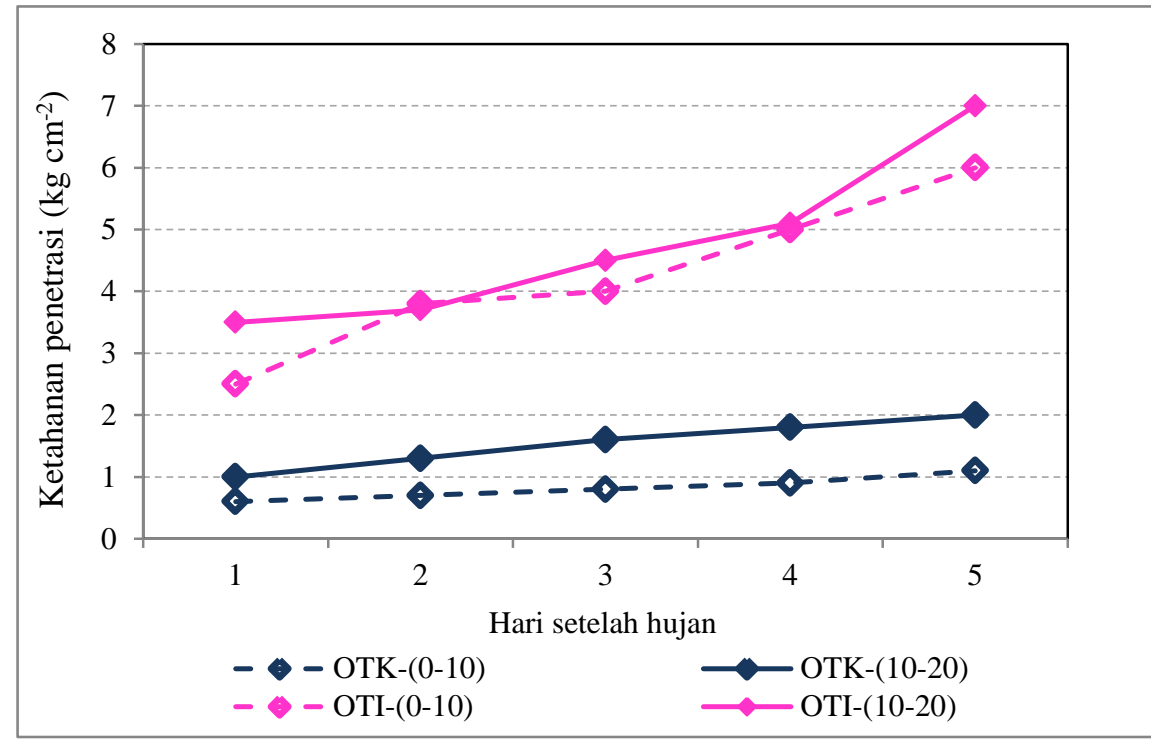

Gambar 3. Ketahanan penetrasi tanah pada berbagai jenis pengolahan tanah, kedalaman tanah dan beberapa hari setelah hujan.

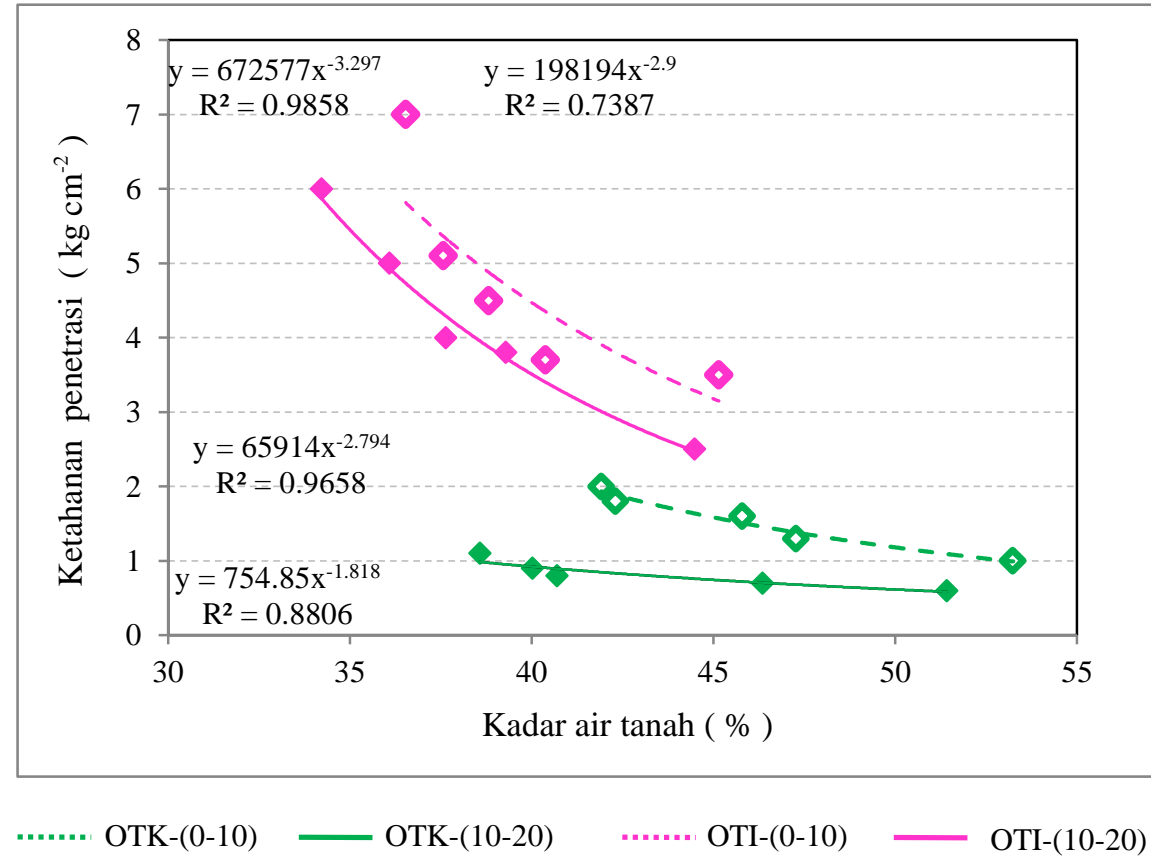

Gambar 4. Hubungan antara kadar air dan ketahanan penetrasi tanah pada lahan olah intensif dan lahan olah konservasi

Pada Gambar 3 terlihat bahwa nilai ketahanan penetrasi tanah pada lahan dengan sistem olah tanah intensif jauh lebih tinggi dibandingkan lahan pengolahan tanah konservasi, baik di kedalaman 0-10 cm maupun 10$20 \mathrm{~cm}$. Hal ini menunjukan bahwa tanah dengan sistem olah intensif lebih keras dibandingkan dengan tanah dengan sistem olah konservasi, sehingga akar tanaman lebih sulit menembus tanah untuk mengambil air dan hara. Seperti yang dikemukakan dalam Brady and Weil (2002), bahwa cara pengolahan tanah sangat mempengaruhi hasil pengolahan tanah, struktur, bobot isi, dan ruang pori tanah yang pada gilirannya akan mempengaruhi tingkat kepadatan suatu tanah.

Gambar 3 juga menunjukkan bahwa pada hari ke4 dan ke-5 di lahan pengolahan tanah intensif memiliki nilai antara $5 \mathrm{~kg} \mathrm{~cm}^{-2}-7 \mathrm{~kg} \mathrm{~cm}^{-2}$ pada kedalaman $0-10 \mathrm{~cm}$ dan 10-20 $\mathrm{cm}$. Hal ini menunjukkan adanya potensi menjadi sangat terhambatnya perakaran tanaman yang terjadi pada lahan tersebut. Nilai normal ketahanan penetrasi tanah untuk pertumbuhan akar secara normal adalah $0-5 \mathrm{~kg} \mathrm{~cm}^{-2}$. Perkembangan akar tanaman mulai terhambat jika ketahanan penetrasi tanah $5 \mathrm{~kg} \mathrm{~cm}^{-2}$. Banyak pertumbuhan akar tanaman tinggal setengahnya jika ketahanan penetrasi akar adalah $20 \mathrm{~kg} \mathrm{~cm}^{-2}$ (Horn and Baumgartl, 2000), bahkan akar tanaman kedelai dan jagung akan sangat terhambat pada keketahanan penetrasi $1 \mathrm{Mpa}\left(10 \mathrm{~kg} \mathrm{~cm}^{-2}\right)$ dan di atas $1 \mathrm{Mpa}$ akar jagung dan kedelai hampir tidak ditemukan (Mazurak dan Pohlman, 1968). 


\section{Hubungan Kadar Air dan Ketahanan Penetrasi Tanah}

Hubungan antara kadar air dan ketahanan penetrasi tanah disajikan pada Gambar 4. Gambar tersebut menunjukkan bahwa ketahanan penetrasi tanah akan meningkat dengan menurunnya kadar air tanah. Hal ini terkait dengan meningkatnya kohesi antar partikel tanah seiring dengan menurunnya kadar air tanah (Jury et al., 2000).

Gambar 4 juga menunjukkan bahwa peningkatan ketahanan penetrasi tanah yang terjadi akibat penurunan kadar air pada tanah dengan sistem olah intensif lebih besar dibandingkan pada tanah dengan sistem olah konservasi, seperti ditunjukkan oleh kurva yang lebih tajam. Demikian juga, terlihat bahwa pada kadar air yang sama, ketahanan penetrasi pada tanah olah intensif lebih besar dibanding pada tanah olah konservasi. Hal ini terjadi karena adanya penyumbatan pori tanah oleh partikel liat akibat pengolahan yang terus menerus. Selain itu, tingginya kandungan liat dan debu dalam tanah dengan sistem olah tanah yang intensif akan menurunkan makroporositas tanah yang pada gilirannya akan berdampak pada ketahanan penetrasi tanah khususnya pada bagian atas tanah. Kenyataan ini sejalan dengan Suprayogo (2004), yang mendapatkan bahwa pembentukan kerak di permukaan tanah (soil crusting) sebagai akibat penyumbatan pori-pori tanah oleh partikel liat akan meningkatkan ketahanan penetrasi tanah.

\section{SIMPULAN}

Lahan dengan sistem olah tanah intensif mempunyai kandungan bahan organik yang lebih rendah dibandingkan lahan dengan sistem olah tanah konservasi.

Sistem olah tanah intesif menyebabkan kemampuan retensi air tanah yang lebih rendah dibandingkan dengan sistem olah tanah konservasi, yang ditunjukan oleh nilai kadar air pada semua $\mathrm{pF}$ yang lebih rendah. Demikian juga dengan kadar air lapang yang selalu lebih rendah pada lahan olah tanah intensif. Jika 5 hari berturut-turut tidak hujan, pada sistem olah tanah intensif, kadar air lapang tanah lapisan atas sudah lebih rendah dari kadar air titik layu permanennya.

Ketahanan penetrasi tanah pada sistem olah tanah intensif lebih tinggi dari sistem olah tanah konservasi. Jika 5 hari berturut-turut tidak hujan, tanah pada sistem olah tanah intensif mempunyai ketahanan penetrasi yang menghambat pertumbuhan akar.

\section{UCAPAN TERIMA KASIH}

Penulis menyampaikan penghargaan dan terima kasih kepada para pegawai Laboratorium, terutama Pak Syaipulloh yang telah banyak membantu dalam analisis tanah, serta semua pihak yang telah banyak membantu selama penelitian berlangsung.

\section{DAFTAR PUSTAKA}

Baskoro, D.P.T. dan S.D. Tarigan. 2007. Karakteristik kelembaban tanah pada beberapa jenis tanah. Jurnal Tanah dan Lingkungan, 9: 77-81.
Bergeret, A. 1977. Ecologically viabble system of production. Ecodeveloptment New. 3 Oktober 1977 : 3-26.

Brady, N.C. and R.R. Weil, 2002. The Nature and Properties of Soils. $13^{\text {th }}$ Edition. Prentice Hall. New Jersey.

Dani, Or and J.M. Wrath. 2000. Water Movement in Soil. In M. E. Summer (ed.). Handbook of Soil Science. CRC Press, Boca Raton-London-New YorkWashington D.C. p. A53-A86.

Gliessman, S.R. 2007. Agroecology: The Ecology of Sustainable Food Sistem. Second Edition. CRC Press. New York.

Horn, R. and T. Baumgartl. 2000. Dynamic Properties of Soils. In M. E. Summer (ed.). Handbook of Soil Science. CRC Press, Boca Raton-London-New York-Washington D.C. p. A19 - A51.

Jury, W.A., W.R. Gardner, and W.H. Gardner. 2001. Soil Physics. $5^{\text {th }}$ Edition. John Wiley and Sons, Inc. New York-Chichester-Brisbane. 329 p.

Mazurak, A. P. and K. Pohlman. 1968. Growth of corn and soybean seedlings as related to soil compaction and matrix suction. Paper presented at the 9 International Soil Conference.

Sinukaban, N. 1990. Pengaruh pengolahan tanah konservasi dan pemberian mulsa jerami terhadap produksi tanaman pangan dan erosi hara. Tanah dan Pupuk, 9: 32-38.

Suprayogo, D., Widianto, P. Purnomosidi, R.H. Widodo, F. Rusiana, Z. Aini, N. Khasanah, dan Z. Kusuma. 2004. Degradasi sifat fisik tanah sebagai akibat alih guna lahan hutan menjadi sistem kopi monokultur: kajian perubahan makroporositas tanah. Agrivita, 26: 60-68.

Swan, J.B., W.H. Paulson, A.E. Peterson, and R.L. Higgs., 1991. Tillage-residue management effects on seedbed physical conditions, corn growth and yield. P.343. In Agronomy Abstracts. Annual Meetings, ASA-CSSA and SSSA. Denver-Colorado.

Syam, A., K. Kariyasa, E. Sujitno, dan Z. Zaini. 1996. Prosiding Lokakarya Evaluasi Hasil Penelitian Usahatani Lahan Kering. Pusat Penelitian Tanah dan Agroklimat. Badan Penelitian dan Pengembangan Pertanian, Departemen Pertanian, Bogor.

Triyono, K. 2007. Pengaruh sistem pengolahan tanah dan mulsa terhadap konservasi sumberdaya tanah. Jurnal Inovasi Pertanian, 6: $11-21$. 